\title{
Effects of Biochar on the Emissions of Greenhouse Gases from Sugarcane Residues Applied to Soils
}

\author{
Thalita Fernanda Abbruzzini' ${ }^{1}$, Mariana Delgado Oliveira Zenero', \\ Pedro Avelino Maia de Andrade ${ }^{1}$, Fernando Dini Andreote ${ }^{1}$, \\ Julio Campo ${ }^{2}$, Carlos Eduardo Pellegrino Cerri ${ }^{1}$ \\ ${ }^{1}$ Department of Soil Science, "Luiz de Queiroz" College of Agriculture, Piracicaba, Brazil \\ ${ }^{2}$ Institute of Ecology, Universidad Nacional Autónoma de México, México D.F., Mexico \\ Email: thalita.ufla@gmail.com
}

How to cite this paper: Abbruzzini, T.F., Zenero, M.D.O., de Andrade, P.A.M., Andreote, F.D., Campo, J. and Cerri, C.E.P. (2017) Effects of Biochar on the Emissions of Greenhouse Gases from Sugarcane Residues Applied to Soils. Agricultural Sciences, 8, 869-886

https://doi.org/10.4236/as.2017.89064

Received: May 5, 2017

Accepted: August 31, 2017

Published: September 5, 2017

Copyright $\odot 2017$ by authors and Scientific Research Publishing Inc. This work is licensed under the Creative Commons Attribution International License (CC BY 4.0).

http://creativecommons.org/licenses/by/4.0/

(c) (i) Open Access

\begin{abstract}
The sugar and bioethanol industry generate large amounts of filter cake and vinasse, residues that are applied to sugarcane fields as conditioners and organic fertilizers. However, these may be significant sources of greenhouse gases emissions to the atmosphere. This study assessed the impact of sugarcane straw biochar on the emissions of $\mathrm{CO}_{2}, \mathrm{CH}_{4}$ and $\mathrm{N}_{2} \mathrm{O}$ promoted by filter cake and vinasse applied to soil, and its effects on the chemical properties and bacterial communities of a Typic Hapludox and a Quartzipsamment. A laboratory incubation was conducted for 100 days with both soils under five treatments: vinasse and filter cake amendment (FV), plus biochar at $10(\mathrm{FV}+$ B10), $20(\mathrm{FV}+\mathrm{B} 20)$ and $50(\mathrm{FV}+\mathrm{B} 50) \mathrm{Mg} \cdot \mathrm{ha}^{-1}$, and a control. Soil pH, available $\mathrm{P}$ and exchangeable base contents increased with biochar added to sandy soil. Mineral N decreased with biochar addition to both soils. The FV treatment increased $\mathrm{CO}_{2}$ emissions by 5-fold and 2.4-fold in sandy and clayey soils, respectively, compared to the control. Moreover, FV $+\mathrm{B} 10$ increased $\mathrm{CO}_{2}$ emissions by $4 \%$ and $6.4 \%$ in sandy and clayey soils, respectively, compared to FV. Cumulative $\mathrm{N}_{2} \mathrm{O}$ emissions in FV were $537 \%$ and $125 \%$ higher in sandy and clayey soils, respectively, compared to the control. Nevertheless, increasing biochar amendment rates reduced $\mathrm{N}_{2} \mathrm{O}$ emissions from $24 \%$ to $34 \%$ in sandy soil, and from $14 \%$ to $56 \%$ in clayey soil. $\mathrm{CH}_{4}$ emissions were negligible. The effects of filter, vinasse and biochar amendments on soil amelioration were closely related to its buffering capacity. Temporal changes on bacterial community structure were more pronounced in the sandy soil compared to clayey, and indicated that $\mathrm{N}_{2} \mathrm{O}$ emission mitigation in clayey soil was
\end{abstract}


directly related to biotic mechanisms, while abiotic mechanisms caused by biochar played a more important role in mitigating $\mathrm{N}_{2} \mathrm{O}$ emissions in sandy soil.

\section{Keywords}

Filter Cake, Fingerprinting, Nitrous Oxide, Pyrolysis Carbon, Soil Fertility, Vinasse

\section{Introduction}

The intensification of green cane harvesting has led to a greater deposition of leaves and tips on soil surface, ranging between 10 and $20 \mathrm{Mg} \cdot \mathrm{ha}^{-1}$ of dry matter, and the amount of sugarcane crop residues generated in Brazil is estimated in 175 million $\mathrm{Mg} \cdot \mathrm{yr}^{-1}$ [1]. Against the claiming demand to use this biomass for bioenergy generation, the Brazilian sugarcane sector has considered the partial removal of the post-harvest residues from soil surface without harming sustainability and yields [2]. On the other hand, the sugar and bioethanol industry generate large amounts of filter cake and vinasse, residues that are applied to sugarcane fields as conditioners and organic fertilizers [3].

Vinasse is an acidic ( $\mathrm{pH} \approx 4.5)$ nutrient-dense effluent that is produced at a rate of approximately $13 \mathrm{~L}$ for every liter of ethanol. Filter cake is a nutrient-rich solid residue from the filtration of sugarcane juice, produced in an average of 8 $\mathrm{kg}$ per ton of processed sugarcane [4]. Despite vinasse and filter cake benefits to conservation agriculture [3], these residues may be significant sources of greenhouse gases (GHG), mainly nitrous oxide $\left(\mathrm{N}_{2} \mathrm{O}\right)$ and methane $\left(\mathrm{CH}_{4}\right)$ [5] [6] [7].

In this context, one of the proposed means to reduce GHG emissions in agriculture is through the use of biochar (charcoal derived from the pyrolysis of biomass). Despite the benefits of biochar applications to soil [8]-[16], studies regarding its combination with other organic residues are still limited. Positive interactions between biochar and organic residues can be expected due to the biological activation of biochar and reduced organic fertilizer mineralization, leading to synergisms between biochar and organic residues [17].

According to [18], the combination of biochar with poultry manure reduced $\mathrm{N}$ losses by volatilization and produced high quality composts. [17] showed that biochar addition to soil in combination with organic fertilizer can stabilize compost-derived organic matter (OM) and increase soil $\mathrm{C}$ sequestration, as well as improve soil fertility over the sole biochar or organic/mineral fertilizer application. Biochar-amended soils have also shown to reduce $\mathrm{CO}_{2}$ emissions [19] in response to vinasse application.

Under the current scenario of climate change, the combination of biochar with organic residues may be an approach to improve nutrient cycling and to fulfill non-agronomic purposes, such as reduction of GHG emissions. The aim of this study was to assess the effects of applying sugarcane straw biochar com- 
bined with vinasse and filter cake on the emissions of $\mathrm{CO}_{2}, \mathrm{CH}_{4}$ and $\mathrm{N}_{2} \mathrm{O}$, chemical properties and bacterial community composition of two contrasting soils (i.e. clayey and sandy tropical soils). It was hypothesized that: i) The effects of biochar amendments on soil amelioration is closely related to soil buffering capacity; ii) biochar suppresses GHG emissions from filter cake and vinasse applied to soils as a function of its application rate; and iii) soil-biochar interactions cause temporal changes in bacterial communities both directly and indirectly, affecting niche-microbe interactions related to $\mathrm{N}_{2} \mathrm{O}$ emission mitigation. For testing these hypotheses an incubation experiment was conducted under controlled environmental conditions (i.e., temperature and moisture), with and without application of vinasse and filter cake combined with addition of biochar at different rates in two contrasting forest soils.

\section{Materials and Methods}

\subsection{Biochar Production and Characterization}

The feedstock for biochar production was straw collected from a sugarcane field within a mill located in Piracicaba, State of Sao Paulo, Brazil. A recently harvested area (i.e., 7 days after unburned mechanized harvesting) was selected since it presented a largeamount of fresh post-harvest residues on soil surface $(\approx$ $10 \mathrm{Mg} \cdot \mathrm{ha}^{-1}$ of dry matter).

Before pyrolysis, the straw particles were cut into fragments of $5 \pm 1 \mathrm{~cm}$. Then, the reactor was cleaned under heating with air injection in order to remove impurities prior to allocation of the raw material. Approximately $3 \mathrm{~kg}$ of feedstock was manually placed into the sample port of the reactor, which consisted of 300- $\times 2400-\mathrm{cm}$ steel cylinder (diameter $\times$ length) closed on one end with a circular steel plate.

The pyrolysis process was carried out under $\mathrm{N}_{2}$ atmosphere, with a final temperature of $450^{\circ} \mathrm{C}\left(\Delta \approx 20^{\circ} \mathrm{C}\right)$ and heating rate of $10^{\circ} \mathrm{C} \cdot \mathrm{min}^{-1}$ for a retention time of 2 hours. The condensable gases were recovered on the other end of the reactor as a liquid (i.e. bio-oil). Non-condensable gases were exhausted to a water tank outside the processing unit to avoid their direct release to the atmosphere.

After completion of pyrolysis, the sample presented homogeneous carbonization and a volume reduction of $30 \%$ to $40 \%$. The pyrolysis process yielded $30 \%$ of biochar, $40 \%$ of liquids (bio-oil) and $30 \%$ of gas, which is within the range observed in most studies for slow pyrolysis [20]. Chemical properties of the feedstock and final biochar are presented in Table 1.

\subsection{Soils and Organic Residues}

Two soils with contrasting texture, a Quartzipsamment (sandy) and a Typic Hapludox (clayey), were collected from two different native forest areas located, respectively, from near Anhembi town, State of Sao Paulo, Brazil (22 $43^{\prime} 31.1^{\prime \prime S}$; $\left.48^{\circ} 01^{\prime} 20.2^{\prime \prime} \mathrm{W}\right)$ and within the ESALQ campus ( $\left.22^{\circ} 42^{\prime} 05.1^{\prime \prime} \mathrm{S} ; 47^{\circ} 37^{\prime} 45.2^{\prime \prime} \mathrm{W}\right)$, Piracicaba, respectively; both located at the State of Sao Paulo, Brazil. Native vege- 
Table 1. Characterization of the feedstock (sugarcane straw) for biochar production, biochar, filter cake and vinasse used in the study.

\begin{tabular}{|c|c|c|c|c|c|c|c|c|}
\hline \multirow{2}{*}{\multicolumn{2}{|c|}{ Residues }} & C & $\mathrm{N}$ & \multirow{2}{*}{$\mathrm{C} / \mathrm{N}$} & $\mathrm{P}$ & $\mathrm{Ca}$ & $\mathrm{Mg}$ & K \\
\hline & & \multicolumn{2}{|c|}{$\mathrm{mg} \cdot \mathrm{g}^{-1}$} & & \multicolumn{4}{|c|}{$\mathrm{mg} \cdot \mathrm{g}^{-1}$} \\
\hline Straw & $5.8(0.1)$ & $479.0(12.0)$ & $8.0(2.0)$ & $59.9(1.3)$ & $1.0(0.1)$ & $7.7(0.2)$ & $1.5(0.5)$ & $9.5(3.5)$ \\
\hline Biochar & $9.2(0.6)$ & $674.6(35.4)$ & $13.8(1.5)$ & $48.9(4.2)$ & $2.2(0.9)$ & $5.1(1.1)$ & $3.2(0.7)$ & $12.5(2.2)$ \\
\hline Filtercake & $6.5(1.1)$ & $133.9(27.2)$ & $8.4(2.3)$ & $15.9(8.9)$ & $10.5(1.1)$ & $10.0(0.8)$ & $1.7(0.3)$ & $1.4(0.5)$ \\
\hline Vinasse & $4.7(0.8)$ & $17.0(8.3)$ & $0.8(0.2)$ & $21.2(4.4)$ & $0.6(0.2)$ & $0.8(0.2)$ & $0.3(0.1)$ & $3.5(0.8)$ \\
\hline
\end{tabular}

Mean (SD), $\mathrm{n}=3$.

tation (seasonal semideciduous forest) soils were chosen to avoid residual effects of filter cake and vinasse application on soil properties [21] [22] [23]. These soils were sampled at the $0-20 \mathrm{~cm}$ layer, air-dried, homogenized, and sieved to $2 \mathrm{~mm}$ before installing the experiment. Soil characteristics are given in Table 2.

Both the filter cake and vinasse were collected fresh from a sugarcane mill located in Piracicaba, State of Sao Paulo, Brazil. Prior the application to experimental units, filter cake was dried at $45^{\circ} \mathrm{C}$ by $48 \mathrm{~h}$ in a forced-air oven, and the dried material was gently crushed and sieved $(<2 \mathrm{~mm})$ before incubation. Vinasse was kept frozen at $-20^{\circ} \mathrm{C}$ until use.

The $\mathrm{pH}$ and chemical characteristics differed considerably among materials (Table 1). Paired comparisons using a Tukey-Kramer HSD test showed that biochar was richer in nutrients $(p<0.05)$, while vinasse showed the lowest concentrations of nutrients among residues.

\subsection{Experimental Set-Up and Design}

The laboratory incubation was conducted with two soils (i.e. sandy and clayey) under five treatments: filter cake and vinasse amendment (FV), plus biochar at three application rates $(\mathrm{FV}+\mathrm{B} 10, \mathrm{FV}+\mathrm{B} 20$ and $\mathrm{FV}+\mathrm{B} 50)$, and control (soilonly). Biochar was applied at $0.4 \%, 0.8 \%$ and $1.9 \%(\mathrm{w} / \mathrm{w})$ to sandy soil, and at $0.5 \%, 1 \%$ and $2.5 \%(\mathrm{w} / \mathrm{w})$ to clayey soil. These additions represent field application rates of 10, 20 and $50 \mathrm{Mg} \cdot \mathrm{ha}^{-1}$ of biochar to soil (assuming an incorporation depth of $20 \mathrm{~cm}$ and considering the bulk density of 1.0 and $1.3 \mathrm{~g} \cdot \mathrm{cm}^{-3}$ for clayey and sandy soil, Table 2). These were then placed in airtight glass jars of $1.4 \mathrm{~L}$ and pre-incubated at $4^{\circ} \mathrm{C}$ for $24 \mathrm{~h}$ to minimize the disturbance effects on microbial communities and soil processes, before starting the incubation at $25^{\circ} \mathrm{C}$ by 100 days.

The amount of filter cake and vinasse applied to all treatments was equivalent to $100 \mathrm{Mg} \cdot \mathrm{ha}^{-1}$ and $100 \mathrm{~m}^{3} \cdot \mathrm{ha}^{-1}$, respectively, which are the application rates commonly used in Brazilian sugarcane fields [24]. Biochar, filter cake and vinasse were thoroughly mixed with the dry soil to obtain a completely homogeneous mixture, and soil moisture was adjusted to $60 \%$ water-filled pore space (WFPS). Replicate jars from each treatment were destructively sampled at dif- 
Table 2. Properties of two incubated soils $(0-20 \mathrm{~cm}$ depth) used to evaluate the combination of biochar with organic residues from sugarcane industry.

\begin{tabular}{|c|c|c|c|c|c|}
\hline \multirow{2}{*}{ Soils } & Sand/Silt/Clay & Bulk density & \multirow{2}{*}{$\mathrm{pH}$} & $\mathrm{C}$ & $\mathrm{N}$ \\
\hline & $\%$ & $\mathrm{~g} \cdot \mathrm{cm}^{-3}$ & & \multicolumn{2}{|c|}{$\mathrm{mg} \cdot \mathrm{g}^{-1}$} \\
\hline Quartzipsamment (sandy) & $90 / 2.2 / 7.8$ & $1.3(0.2)$ & $4.1(0.1)$ & $13.0(1.0)$ & $1.0(0.0)$ \\
\hline TypicHapludox (clayey) & $40 / 28 / 32$ & $1.0(0.1)$ & $6.2(0.0)$ & $39.0(2.0)$ & $3.0(0.0)$ \\
\hline
\end{tabular}

ferent times ( $\mathrm{n}=2$ at 30 days and $\mathrm{n}=4$ at 100 days) to characterize soil chemical attributes and bacterial communities.

\subsection{Soil Chemical Characteristics}

To assess the chemical characteristics of the incubated soils over time, destructive sampling was performed after 30 and 100 days of incubation, by removing four replicates per treatment at 30 days $(n=4)$, and the four remaining replicates after 100 days. Subsamples were kept at $-20^{\circ} \mathrm{C}$ for subsequent determination of mineral $\mathrm{N}$ (i.e. ammonium $\left(\mathrm{NH}_{4}{ }^{+}-\mathrm{N}\right)$ and nitrate $\left(\mathrm{NO}_{3}{ }^{-}-\mathrm{N}\right)$ ) by extraction (1:5 w:v) in a $1 \mathrm{M} \mathrm{KCl}$ solution. Extracts were immediately frozen and kept for further measurement using the flow injection analysis method [25].

The $\mathrm{pH}$ was determined in $\mathrm{H}_{2} \mathrm{O}$ using a biochar: solution ratio of 1:2 (w:v) and agitation at $220 \mathrm{rpm}$ for $30 \mathrm{~min}$. Samples were left to settle for $30 \mathrm{~min}$ before $\mathrm{pH}$ was determined with a $\mathrm{pH}$ electrode. Available $\mathrm{P}$ and exchangeable cations $\left(\mathrm{K}^{+}, \mathrm{Ca}^{2+}, \mathrm{Mg}^{2+}\right)$ were determined according to the method proposed by [26]. Sulfur content was determined by extraction in monocalcium phosphate $0.01 \mathrm{M}$ and subsequent quantification by colorimetry [27]. The exchangeable acidity was determined by extraction of $\mathrm{H}^{+}$and $\mathrm{Al}^{3+}$ with a $\mathrm{Ca}(\mathrm{OAc})_{2} 1.0 \mathrm{M}$ solution buffered to $\mathrm{pH} 7$ [27].

\subsection{Gas Sampling}

The fluxes of $\mathrm{CO}_{2}, \mathrm{~N}_{2} \mathrm{O}$ and $\mathrm{CH}_{4}$ in each treatment were estimated by determining the concentration of gases in the jars' headspace over the experimental duration. Each incubation unit (i.e. glass jar containing each replicated treatment) was closed and samples of the headspace gas were taken at time zero and final using $20 \mathrm{~mL}$ syringes. After completion of sampling event (i.e. gas buildup), the jars were opened to flush out its gaseous contents and closed again for the next sampling, which occurred daily for the first 7 days of incubation and after this period was performed at intervals of 2 to 3 days until final incubation time (100 days).

The concentrations of $\mathrm{CO}_{2}, \mathrm{~N}_{2} \mathrm{O}$ and $\mathrm{CH}_{4}$ at each sampling time were determined using a gas chromatograph (SRI 8610C, SRI Instruments, Torrance, USA), and daily fluxes of $\mathrm{CO}_{2}\left(\mathrm{mg} \mathrm{CO}_{2}-\mathrm{C} \cdot \mathrm{m}^{-2} \cdot \mathrm{day}^{-1}\right), \mathrm{N}_{2} \mathrm{O}\left(\mu \mathrm{g} \mathrm{N} \mathrm{N}_{2} \mathrm{O}-\mathrm{N} \cdot \mathrm{m}^{-2} \cdot\right.$ day $\left.^{-1}\right)$ and $\mathrm{CH}_{4}\left(\mu \mathrm{g} \mathrm{CH}_{4}-\mathrm{C} \cdot \mathrm{m}^{-2} \cdot \mathrm{day}^{-1}\right)$ were calculated from the time versus gas concentration data using linear regression. These data were then used to calculate the cumulative emissions by the linear interpolation of data points between days and numerical integration of the area under curve using the trapezoid rule [28]. 


\subsection{Bacterial Communities}

After 30 and 100 days of incubation, samples of $400 \mathrm{mg}$ of soil from each treatment were subjected to a total DNA extraction using the Power Soil DNA isolation kit (Mo Bio, Carlsbad, EUA), following the manufactory instructions. DNA extraction and integrity were assessed by $1 \%$ agarose gel electrophoresis performed at $100 \mathrm{~W}$ and $400 \mathrm{~mA}$ for $50 \mathrm{~min}$, followed by staining with ethidium bromide and photo documentation under ultra-violet light (transluminator, Storm 845-GE Healthcare Life Sciences, Piscataway, NJ, USA).

The amplification of the V6 region of ribosomal gene 16S rDNA was performed with primers F968/GC [29] and R1378 [30]. The PCR reaction was performed in a total volume of $50 \mu \mathrm{L}$, with each reagent in final concentration of $1 \mathrm{X}$ PCR Buffer; $0.2 \mathrm{mM}$ of each dNTP; $3.5 \mathrm{mM}$ of $\mathrm{MgCl} 2$; $0.2 \mathrm{pMol}$ of each oligonucleotide; 1U-Taq DNA polymerase (Fermentas, Burlington, Canada); and 1 $\mu \mathrm{L}$ of DNA sample (20 $\mathrm{ng})$.

The PCR reaction was run in Veriti Thermal Cycler (Applied Biosystems, Waltham, USA) in the following reaction conditions: initial denaturation at $94^{\circ} \mathrm{C}$ for $3 \mathrm{~min}$, followed by 35 cycles of denaturation at $94^{\circ} \mathrm{C}$ for $1 \mathrm{~min}, 53^{\circ} \mathrm{C}$ for $40 \mathrm{~s}$, extension at $72^{\circ} \mathrm{C}$ for $40 \mathrm{~s}$ and a final extension at $72^{\circ} \mathrm{C}$ for $10 \mathrm{~min}$.

The DGGE was performed using the phorU2 systems (Ingeny International, Goes, The Netherlands). The PCR products were loaded onto $6 \%(\mathrm{w} / \mathrm{v})$ polyacrylamide gels with denaturing gradients of $45 \%-65 \%$ (urea $7 \mathrm{M}$ and formamide $40 \%$ ). The gels were run for $16 \mathrm{~h}$ at $100 \mathrm{~V}$ and $60^{\circ} \mathrm{C}$ and stained with SYBR Green I (Invitrogen, Breda, The Netherlands). The DGGE gels were photodocumented with Storm 845 (General Electric) and analyzed using the Image Quant TL unidimensional (Amersham Biosciences, Amersham, UK, v.2003) [31], where band patterns were converted into abundance matrices of bands.

\subsection{Statistical Analyses}

Model residuals were tested for normal distribution using quantile-quantile plot and the Shapiro-Wilk test. A nested analysis of variance (Nested ANOVA) was carried out to the results regarding soil chemical attributes. Post-hoc Tukey HSD test was applied for the comparison of mean values between and within treatments (over the incubation period). The mean cumulative GHG fluxes obtained for all treatments were also submitted to ANOVA and Tukey test. All statistical analyses were carried out using the software R [32]. Regarding the bacterial groups, a Permanova test was performed to describe the significance of incubation period, doses of biochar and their interaction under 999 random permutations. Within these parameters, it was perfomed a principal coordinate analysis (PCoA) based in the BrayCurtis algorithm [33]. In addition, analysis of similarities (ANOSIM) was conducted to determined the significance of grouping patterns. These statistical analyses were performed using Past Statistics 1.90 program [34]. 


\section{Results and Discussion}

\subsection{Sugarcane Residues and Biochar Effects on Soil Chemical Attributes}

Biochar amendment at $50 \mathrm{Mg} \cdot \mathrm{ha}^{-1}(\mathrm{FV}+\mathrm{B} 50)$ to sandy soil significantly increased $\mathrm{pH}$ after 30 days of incubation compared to the other treatments (Table 3). However, the subsequent evaluation (100 days) showed a significant decrease in soil $\mathrm{pH}$ among treatments (Table 3 ). In contrast, application of FV plus biochar did not have a significant effect on $\mathrm{pH}$ in clayey soil (Table 3 ).

Table 3. Chemical attributes of sandy and clayey soil matrixes after 30 and 100 days of incubation with sugarcane straw biochar combined with residues from the sugarcane industry.

\begin{tabular}{|c|c|c|c|c|c|c|c|c|}
\hline \multirow{3}{*}{ Treatments } & \multirow{2}{*}{$\mathrm{pH}$} & $\mathrm{P}$ & $\mathrm{Ca}$ & $\mathrm{Mg}$ & $\mathrm{K}$ & $\mathrm{H}+\mathrm{Al}$ & $\mathrm{NH}_{4}^{+}$ & $\mathrm{NO}_{3}^{-}$ \\
\hline & & $\mathrm{mg} \cdot \mathrm{dm}^{-3}$ & \multicolumn{3}{|c|}{$\mathrm{mmol}_{\mathrm{c}} \cdot \mathrm{dm}^{-3}$} & & \multicolumn{2}{|c|}{$\mathrm{mg} \cdot \mathrm{kg}^{-1}$} \\
\hline & \multicolumn{8}{|c|}{ Sandy-30 days } \\
\hline Control & $4.3 \mathrm{Ac}$ & $8.0 \mathrm{Ac}$ & $3.3 \mathrm{Ac}$ & $3.3 \mathrm{Ac}$ & $1.6 \mathrm{Ad}$ & 15.6 Aa & $17.3 \mathrm{Ab}$ & $51.9 \mathrm{Ab}$ \\
\hline $\mathrm{FV}$ & $6.3 \mathrm{Ab}$ & $53.6 \mathrm{Ab}$ & $22.7 \mathrm{Aab}$ & $7.0 \mathrm{Ab}$ & $3.8 \mathrm{Ac}$ & $5.3 \mathrm{Ab}$ & $24.7 \mathrm{Aa}$ & $62.5 \mathrm{Aa}$ \\
\hline $\mathrm{FV}+\mathrm{B} 10$ & $6.2 \mathrm{Ab}$ & $68.3 \mathrm{Ab}$ & $25.7 \mathrm{Aa}$ & $8.0 \mathrm{Aab}$ & $8.9 \mathrm{Bb}$ & $5.1 \mathrm{Ab}$ & $7.0 \mathrm{Abc}$ & $22.1 \mathrm{Bc}$ \\
\hline $\mathrm{FV}+\mathrm{B} 20$ & $6.2 \mathrm{Ab}$ & $67.0 \mathrm{Ab}$ & $26.3 \mathrm{Aa}$ & 8.0 Aab & $12.0 \mathrm{Bb}$ & $5.1 \mathrm{Ab}$ & $9.2 \mathrm{Ab}$ & $27.9 \mathrm{Bc}$ \\
\hline \multirow[t]{2}{*}{$\mathrm{FV}+\mathrm{B} 50$} & $6.6 \mathrm{Aa}$ & $92.0 \mathrm{Aa}$ & $20.7 \mathrm{Ab}$ & $9.0 \mathrm{Aa}$ & $14.5 \mathrm{Ba}$ & $4.8 \mathrm{Ab}$ & $6.1 \mathrm{Ac}$ & $30.9 \mathrm{Ac}$ \\
\hline & \multicolumn{8}{|c|}{ Sandy-100 days } \\
\hline Control & $4.1 \mathrm{Ad}$ & $7.0 \mathrm{Ac}$ & $3.7 \mathrm{Ac}$ & $3.0 \mathrm{Ab}$ & $1.3 \mathrm{Ad}$ & $16.0 \mathrm{Ba}$ & $1.2 \mathrm{Cc}$ & $56.9 \mathrm{Aab}$ \\
\hline $\mathrm{FV}$ & $5.2 \mathrm{Bc}$ & $28.0 \mathrm{Bb}$ & $15.0 \mathrm{Bb}$ & $6.7 \mathrm{Aa}$ & $3.9 \mathrm{Ac}$ & $6.0 \mathrm{Ab}$ & $1.0 \mathrm{Cc}$ & $49.5 \mathrm{ABb}$ \\
\hline $\mathrm{FV}+\mathrm{B} 10$ & $5.4 \mathrm{Bbc}$ & $40.7 \mathrm{Bab}$ & $21.0 \mathrm{Ba}$ & $8.0 \mathrm{Aa}$ & $10.3 \mathrm{Ab}$ & $5.8 \mathrm{Ab}$ & $1.9 \mathrm{Bbc}$ & $68.1 \mathrm{Aa}$ \\
\hline $\mathrm{FV}+\mathrm{B} 20$ & 5.6 Bab & $35.7 \mathrm{Bb}$ & $20.3 \mathrm{Ba}$ & $7.7 \mathrm{Aa}$ & $13.6 \mathrm{Ab}$ & $5.7 \mathrm{Ab}$ & $4.1 \mathrm{Ba}$ & $61.1 \mathrm{Aa}$ \\
\hline \multirow[t]{2}{*}{$\mathrm{FV}+\mathrm{B} 50$} & $5.8 \mathrm{Ba}$ & $55.3 \mathrm{Ba}$ & $21.0 \mathrm{Aa}$ & $8.0 \mathrm{Aa}$ & $15.5 \mathrm{Aa}$ & $5.8 \mathrm{Ab}$ & $3.2 \mathrm{Bab}$ & $36.6 \mathrm{Ab}$ \\
\hline & \multicolumn{8}{|c|}{ Clayey-30 days } \\
\hline Control & $6.5 \mathrm{Aab}$ & $28.0 \mathrm{Ac}$ & $96.5 \mathrm{Bb}$ & $20.0 \mathrm{Bc}$ & $4.0 \mathrm{Ac}$ & $12.0 \mathrm{Ba}$ & $36.5 \mathrm{Aa}$ & $89.2 \mathrm{Aa}$ \\
\hline FV & $6.7 \mathrm{Aa}$ & $98.5 \mathrm{Aab}$ & $103.5 \mathrm{Bb}$ & $23.6 \mathrm{Cb}$ & $9.1 \mathrm{Aab}$ & $5.0 \mathrm{Bbc}$ & $46.9 \mathrm{Aa}$ & 125.7 Aa \\
\hline $\mathrm{FV}+\mathrm{B} 10$ & $6.6 \mathrm{Aab}$ & $116.0 \mathrm{ABab}$ & $142.0 \mathrm{Ba}$ & $29.6 \mathrm{Aa}$ & $7.0 \mathrm{Abc}$ & $6.0 \mathrm{Bb}$ & $12.8 \mathrm{Ab}$ & $38.4 \mathrm{Bb}$ \\
\hline $\mathrm{FV}+\mathrm{B} 20$ & 6.5 Aab & $131.5 \mathrm{Aa}$ & $105.0 \mathrm{Cb}$ & $28.0 \mathrm{Ba}$ & 8.6 ABab & $6.0 \mathrm{Bb}$ & $10.5 \mathrm{ABb}$ & $46.8 \mathrm{Bb}$ \\
\hline \multirow[t]{2}{*}{$\mathrm{FV}+\mathrm{B} 50$} & $6.5 \mathrm{Ab}$ & $70.5 \mathrm{Abc}$ & $97.0 \mathrm{Bb}$ & 26.0 ABab & $10.7 \mathrm{Aa}$ & $5.0 \mathrm{Bb}$ & $10.9 \mathrm{Ab}$ & $42.5 \mathrm{Bb}$ \\
\hline & \multicolumn{8}{|c|}{ Clayey-100 days } \\
\hline Control & $5.8 \mathrm{Bb}$ & $20.0 \mathrm{Ab}$ & $166.0 \mathrm{Aa}$ & $27.0 \mathrm{Ac}$ & $3.5 \mathrm{Ac}$ & $12.5 \mathrm{Aa}$ & $1.6 \mathrm{Ba}$ & $79.5 \mathrm{Aa}$ \\
\hline FV & $6.3 \mathrm{Ba}$ & $87.0 \mathrm{Aa}$ & $164.0 \mathrm{Aa}$ & $36.0 \mathrm{Aa}$ & $5.2 \mathrm{Bbc}$ & $6.0 \mathrm{Ab}$ & $2.1 \mathrm{Ba}$ & $64.5 \mathrm{Ba}$ \\
\hline $\mathrm{FV}+\mathrm{B} 10$ & $6.3 \mathrm{Ba}$ & $120.0 \mathrm{Aa}$ & 165.0 Aa & $33.0 \mathrm{Aa}$ & $5.7 \mathrm{Ab}$ & $5.0 \mathrm{Abc}$ & $4.6 \mathrm{Aa}$ & $71.3 \mathrm{Aa}$ \\
\hline $\mathrm{FV}+\mathrm{B} 20$ & $6.3 \mathrm{Ba}$ & $81.5 \mathrm{Ba}$ & $160.5 \mathrm{Aab}$ & $32.0 \mathrm{Aab}$ & $6.1 \mathrm{Bab}$ & $5.3 \mathrm{Ac}$ & $2.0 \mathrm{Ba}$ & $85.8 \mathrm{Aa}$ \\
\hline $\mathrm{FV}+\mathrm{B} 50$ & $6.3 \mathrm{Ba}$ & $102.0 \mathrm{Aa}$ & $146.0 \mathrm{Ab}$ & $28.0 \mathrm{Abc}$ & $6.9 \mathrm{Ba}$ & $5.3 \mathrm{Bd}$ & $2.8 \mathrm{Aa}$ & $58.3 \mathrm{Ba}$ \\
\hline
\end{tabular}

Values presented are means, $\mathrm{n}=4$ for 30 and 100 days. Means followed by the same uppercase letter compare within treatments between periods. Means followed by the same lowercase letter compare between treatments within period. Means do not differ statistically at $5 \%$ probability by Tukey's test. The treatments are: soil with filter cake and vinasse (FV); plus biochar at $10(\mathrm{FV}+\mathrm{B} 10), 20(\mathrm{FV}+\mathrm{B} 20)$ and $50(\mathrm{FV}+\mathrm{B} 50)$ $\mathrm{Mg} \cdot \mathrm{ha}^{-1}$. 
The application of FV + B50 in sandy soil increased available P by $72 \%$ higher compared to FV after 30 days of incubation (Table 3). However, available $\mathrm{P}$ concentrations over time behaved similarly to $\mathrm{pH}$, with a decrease varying between $40(\mathrm{FV}+\mathrm{B} 50)$ and $48 \%(\mathrm{FV})$ after 100 days of incubation.

Increased soil $\mathrm{pH}$ have been attributed to biochar richness in alkaline cations suchas $\mathrm{Ca}^{2+}, \mathrm{Mg}^{2+}$ and $\mathrm{K}^{+}$, which are released through dissolution of the mineral phase to the soil solution [8] [15].

The further reduction in soil $\mathrm{pH}$ observed over time may be an effect of vinasse (Table 3). [35] observed increase of soil $\mathrm{pH}$ as function of vinasse dose applied to soil. However, after 100 days of incubation the soil $\mathrm{pH}$ where vinasse was applied reached that of the control, indicating its transient effect on $\mathrm{pH}$ levels. It is important to note that the steeper decrease of $\mathrm{pH}$ in vinasse and filter cake amendent compared to increasing additional biochar application (Table 3) can be assigned to the real potential of pure biochar to improve soil acidic conditions.

The increase in sandy soil $\mathrm{pH}$ caused by biochar precipitated ions $\mathrm{Al}^{3+}$ and decreased potential acidity (Table 3 ), which often are major constraints for agricultural productivity in highly weathered tropical soils [36]. This $\mathrm{pH}$ rise also led to a greater $\mathrm{P}$ availability from filter cake, a rich-P residue (Table 1 ) with about $50 \%$ of its total $\mathrm{P}$ available in the short-term under favourable soil conditions [24]. As expected, the non-significant changes in $\mathrm{pH}$ for the clayey soil (Table 3) indicate that the extent of these changes will strongly depend on the soil $\mathrm{pH}$ buffering capacity [14].

All applications increased the cation exchange capacity (CEC) in sandy soil (Table 3). After 100 days of incubation, CEC increased from $43 \%$ in the $\mathrm{FV}+$ $\mathrm{B} 10$ to $59 \%$ in the $\mathrm{FV}+\mathrm{B} 50$ treatment compared to $\mathrm{FV}(P<0.05)$. In contrast, applications did not have a significant effect on CEC of the clayey soil after 100 days $(P>0.05)$.

The impacts of organic amendments on cation exchange capacity (CEC) are generally more pronounced in sandy soils, while for soils that already contain higher levels of organic matter and clay these impacts may be inconsequential [13]. The results show that nutrient retention can be improved even more by the addition of biochar to soils, especially to those with low ion-retention capacity. It is assumed that slow oxidation occurs on the edges of the aromatic backbone of biochar by both biotic [37] and abiotic processes [10], forming carboxylic groups and sustainably increasing CEC [38].

After 30 days of incubation, the FV treatment increased the concentrations of $\mathrm{NH}_{4}^{+}-\mathrm{N}$ and $\mathrm{NO}_{3}^{-}-\mathrm{N}$ in sandy soil by $43 \%$ and by $20 \%$, respectively, compared to the control (Table 3 ). In contrast, in this same period, increasing doses of biochar resulted in a decreased of the mineral $\mathrm{N}$ concentrations (by $63 \%$ in the case of $\mathrm{FV}+\mathrm{B} 10$ and by $75 \%$ in the case of $\mathrm{FV}+\mathrm{B} 50$ for $\mathrm{NH}_{4}^{+}-\mathrm{N}$; and by $50 \%$ $(\mathrm{FV}+\mathrm{B} 10)$ and $65 \%(\mathrm{FV}+\mathrm{B} 50)$ for $\left.\mathrm{NO}_{3}^{-}-\mathrm{N}\right)$ compared to $\mathrm{FV}(P<0.05)$. After 100 days of incubation, it was observed a steep decrease in $\mathrm{NH}_{4}^{+}-\mathrm{N}$ followed by a concomitant increase in $\mathrm{NO}_{3}^{-}-\mathrm{N}$ among treatments in sandy soil. 
The FV treatment in clayey soil did not affect $\mathrm{NH}_{4}^{+}-\mathrm{N}$ and $\mathrm{NO}_{3}^{-}-\mathrm{N}$ concentrations compared to the control $(P>0.05)$ (Table 3$)$. Biochar addition decreased the mineral $\mathrm{N}$ concentrations in clayey soil compared to $\mathrm{FV}$ by 76 for $\mathrm{NH}_{4}^{+}-\mathrm{N}$ and $66 \%$ for $\mathrm{NO}_{3}^{-}-\mathrm{N}$ after 30 days $(P<0.05)$. There were no significant differences as a function of biochar application rates $(P>0.05)$. Nevertheless, the subsequent evaluation (100 days) showed no significant differences between applications and the control for both $\mathrm{NH}_{4}^{+}-\mathrm{N}$ and $\mathrm{NO}_{3}^{-}-\mathrm{N}$ concentrations $(P>$ 0.05).

The initially lower mineral $\mathrm{N}$ with increasing biochar rate to both sandy and clayey soils (Table 3 ) may indicate the adsorption of $\mathrm{NH}_{4}^{+}-\mathrm{N}$ and $\mathrm{NO}_{3}^{-}-\mathrm{N}$ onto biochar. Indeed, biochar may tighten the soil $\mathrm{N}$ cycling through direct sorption of mineral $\mathrm{N}$, organic $\mathrm{N}$ compounds, enzymes and gases, including $\mathrm{N}_{2} \mathrm{O}$ [11] [39] [40]. It has been suggested that physical entrapment in biochar pores may be responsible for removing $\mathrm{NH}_{4}^{+}$from soil solution, which is a possible mechanism given the diameter of the $\mathrm{NH}_{4}^{+}$ion $(286 \mathrm{pm})$ and the wide range of pore sizes in biochars [41].

The enhanced $\mathrm{NO}_{3}^{-}$concentrations in soil solution at biochar amendments of 10 and $20 \mathrm{Mg} \cdot \mathrm{ha}^{-1}$ after 100 days of incubation, especially in sandy soil (Table 3), may be due to the lower ability of biochar to retain $\mathrm{NO}_{3}{ }^{-}$compared to $\mathrm{NH}_{4}{ }^{+}$ [39] [42]. Biochar can sorb $\mathrm{NH}_{4}^{+}$through acid surface functional groups (e.g. carboxyl and hydroxyl) via cation exchange [9], thus reducing its availability for autotrophic conversion to $\mathrm{NO}_{3}^{-}$for some period of time.

Also, autotrophic nitrification may have been stimulated by high $\mathrm{pH}$ microsites of biochar [11]. Recently, [43] have found that nitrification was increased due to a greater $\mathrm{NH}_{4}^{+}$substrate supply for autotrophic nitrifiers. As the exact mechanism involved in the adsorption of $\mathrm{N}$ forms onto biochar and the effect of time on these processes remain to be understood, all of these phenomena are possible explanation for the enhanced nitrification with biochar addition to soil.

The results of mineral $\mathrm{N}$ also suggest that some microbial $\mathrm{N}$ immobilization had also been taking place at the highest rate of biochar amendment, since the removal of $\mathrm{NH}_{4}^{+}$and $\mathrm{NO}_{3}^{-}$from soil solution prevailed after 100 days of incubation for this treatment (Table 3 ). In this case, the highest biochar dose may have contributed with a greater proportion of bioavailable $\mathrm{C}$, such as residual bio-oils, resulting in microbial demand for inorganic $\mathrm{N}$ present in the soil solution.

Generally, the abovementioned results indicated that, under the same experimental conditions the soil amelioration was closely related to its buffering capacity. In other words, the higher the soil CEC and its initial nutrient concentrations, the greater the soil buffering capacity and lower the effect of pure biochar and its combination with organic residues on soil chemical attributes.

\subsection{Cumulative GHG Emissions from Sugarcane Residues and Biochar}

The FV application increased $\mathrm{CO}_{2}$ emissions from the sandy soil by 5 -fold com- 
pared to the control (Figure 1). When the sandy soil was treated with FV + B10 and $\mathrm{FV}+\mathrm{B} 20$ the $\mathrm{CO}_{2}$ emissions by 4 and $8 \%$, respectively, in comparison to soil that received $\mathrm{F} \mathrm{V}(P<0.05)$. The $\mathrm{FV}+\mathrm{B} 50$ application decreased the $\mathrm{CO}_{2}$ emissions by $11 \%$ compared to $\mathrm{FV}+\mathrm{B} 20$ application $(P<0.05)$. In clayey soil, the $\mathrm{FV}$ treatment increased $\mathrm{CO}_{2}$ emissions by 2.4-fold in comparison to the control (Figure 1). In addition, soils with $\mathrm{FV}+\mathrm{B} 10$ increased other $6.4 \%$ the $\mathrm{CO}_{2}$ emissions in comparison to FV. In contrast, soil that received FV + B20 and FV + B50 decreased the $\mathrm{CO}_{2}$ emissions by $11 \%$ and $8 \%$, respectively, compared to $\mathrm{FV}$ $+\mathrm{B} 10(P<0.05)$.

The addition of filter cake to soil has been shown to increase $\mathrm{CO}_{2}$ efflux. [19] found that filter cake amendment resulted in a 100 -fold increased in $\mathrm{CO}_{2}$ emissions compared to the unamended soil (control), likely due to the immediate utilization of labile sugars present in this residue. However, non-significant emissions of $\mathrm{N}$ applied as filter cake have been found in previous studies [5] [7].

Besides the high biochemical oxygen demand of vinasse, which causes a temporally reduced environment after its application to soil [35], the high amounts of bioavailable $\mathrm{C}$ in this residue can also fuel nitrification and denitrification processes. In plant cane, [5] observed that vinasse was associated with an increase in $\mathrm{N}_{2} \mathrm{O}$ emissions of about $1060 \mathrm{~kg} \mathrm{CO} \mathrm{CO}_{2}$-eq.ha ${ }^{-1} \cdot \mathrm{yr}^{-1}$, and with an increase in $\mathrm{CO}_{2}$ emissions of about $965 \mathrm{~kg} \mathrm{CO}$-eq.ha ${ }^{-1} \cdot \mathrm{yr}^{-1}$ compared to the mineral fertilizer plots.

The slight increase in cumulative $\mathrm{CO}_{2}$ emissions with biochar amendment at 10 and $20 \mathrm{Mg} \cdot \mathrm{ha}^{-1}$ may be attributed to the mineralization of easily available biochar-C at early stages of incubation. The labile C compounds of biochar combined with the high $\mathrm{pH}$ of this material (Table 1) may cause rapid changes in microbial activity [44] when applied to soil, and stimulate fast growing ( $r$-strategists) microbes that are adapted to respond quickly to newly available $\mathrm{C}$

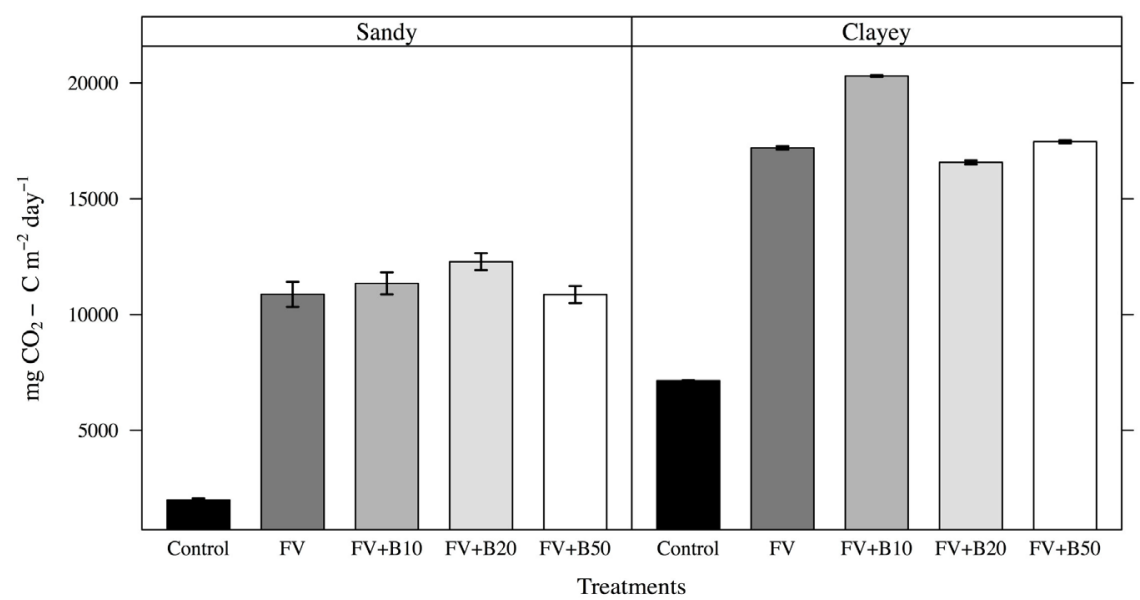

Figure 1. Mean cumulative fluxes of $\mathrm{CO}_{2}$ measured over the incubation period (100 days) in sandy and clayey soil matrixes. Error bars are standard deviation (SD). The treatments are: soil with filter cake and vinasse $(\mathrm{FV})$; plus biochar at $10(\mathrm{FV}+\mathrm{B} 10), 20(\mathrm{FV}+\mathrm{B} 20)$ and $50(\mathrm{FV}+\mathrm{B} 50) \mathrm{Mg} \cdot \mathrm{ha}^{-1}$. 
sources, thereby increasing biochar-C mineralization [45] [46]. However, this phenomenon tends to decrease in the short-term due to the depletion of labile SOC [16].

An interesting outcome from both incubated sandy and clayey soils was that the highest biochar rate to soil dropped $\mathrm{CO}_{2}$ emissions down to the levels comparable to vinasse and filter cake amendment. Although the understanding of the stability biochar $C$ in soil has improved in recent years [16] [45] [46], there is a lack of knowledge about how both the soil- and biochar- $\mathrm{C}$ mineralization are affected as a function of biochar amount applied to soil.

According to [47], composting with biochar caused a positive priming (increased $\mathrm{C}$ mineralization) on non-biochar composting material at low (up to $1 \mathrm{w} \%$ ) biochar concentrations, while at high (up to $50 \mathrm{w} \%$ ) biochar concentrations negative priming (decreased non-biochar $\mathrm{C}$ mineralization) was observed. Moreover, [48] reported that the amount of biochar added to soil is inversely proportional to the impact of priming effect on $\mathrm{C}$ abatement potential.

The FV treatment also increased the $\mathrm{N}_{2} \mathrm{O}$ emissions from the soils (by 5-fold in the case of the sandy soil and by $125 \%$ in the case of clayey soil) in comparison to the control (Figure 2). In contrast, increase in biochar applications decreased the $\mathrm{N}_{2} \mathrm{O}$ emissions by $24 \%(\mathrm{FV}+\mathrm{B} 10)$ and by $34 \%(\mathrm{FV}+\mathrm{B} 50)$ in sandy soil, and by $14 \%(\mathrm{FV}+\mathrm{B} 10)$ and $56 \%(\mathrm{FV}+\mathrm{B} 50)$ in clayey soil in comparison to FV application only $(\mathrm{P}<0.05)$.

[6] observed significantly higher $\mathrm{N}_{2} \mathrm{O}$ emissions in the first days after vinasse application to sugarcane fields. The same authors concluded that the ferti-irrigation with vinasse reduced soil aeration and increased the availability of labile $\mathrm{C}$ to microorganisms, causing microsite of anaerobiosis due to a higher demand of $\mathrm{O}_{2}$ and stimulating denitrification processes in soil.

The mechanisms by which some biochars could induce mitigation of soil $\mathrm{N}_{2} \mathrm{O}$

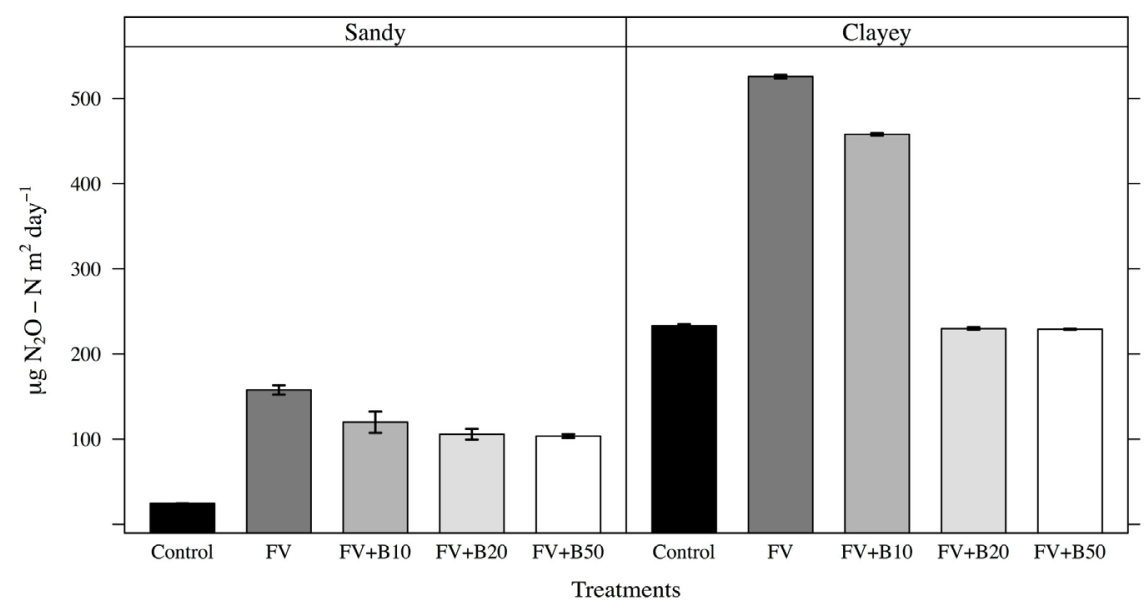

Figure 2. Mean cumulative fluxes of $\mathrm{N}_{2} \mathrm{O}$ measured over the incubation period (100 days) in sandy and clayey soil matrixes. Error bars are standard deviation (SD). The treatments are: soil with filter cake and vinasse (FV); plus biochar at $10(\mathrm{FV}+\mathrm{B} 10), 20(\mathrm{FV}+\mathrm{B} 20)$ and $50(\mathrm{FV}+\mathrm{B} 50) \mathrm{Mg} \cdot \mathrm{ha}^{-1}$. 
emissions remain elusive [12] [13], and will most likely be a function of the biochar, soil properties and their interaction. Primarily, the feedstock from which biochar is produced, in particular its chemical (e.g. available $\mathrm{N}$, ash content, acid neutralizing capacity, aliphatic to aromatic $\mathrm{C}$ ratio etc.) and physical properties (e.g. surface area, particle size, sorption capacity etc.), have a significant impact on $\mathrm{N}_{2} \mathrm{O}$ emissions.

Also, biochar application to soil may affect $\mathrm{N}_{2} \mathrm{O}$ emissions by changing soil physical, chemical and biological properties, which lead to several biotic and abiotic mechanisms that, operating concurrently, control $\mathrm{N}$ mineralization-immobilization and nitrification or denitrification processes in soil. The significant decrease in $\mathrm{N}_{2} \mathrm{O}$ emissions as a function of biochar application rate, especially in clayey soil, could have been favored by increased soil aeration, which in turn reduced anaerobic microsites that favourdenitrification.

Finally, the $\mathrm{CH}_{4}$ fluxes from the both soils (i.e., sandy and clayey soils) were negligible $\left(0.01 \mu \mathrm{g} \mathrm{CH}_{4}-\mathrm{C} \cdot \mathrm{m}^{-2} \cdot \mathrm{day}^{-1}\right)$, and did not showed significant effects of treatments and of soil matrixes (data not showed).

\subsection{Bacterial Communities Shifts upon Biochar Addiction to Soil}

The Permanova analysis revealed that the distribution of bacterial communities in both sandy and clayey soils was influenced by the experimental duration, application rates of biochar, and the interaction of these factors (Table 4). Moreover, the PCoA of DGGE band patterns showed higher temporal changes in bacterial community structure comparing 30 and 100 days of incubation in sandy soil ( $\mathrm{R}=0.70, p=0.0001)$ (Figure 3 ), while clayey soil showed barely separable bacterial groups $(\mathrm{R}=0.24, p=0.0001)$ (Figure 4$)$.

As abovementioned, biochar application to soil might be a pathway of microbial selection and activity [49]. The large surface area and amount of pores in biochar create new niches of microbe colonization, favouring the shifts in bac-

Table 4. PERMANOVA analyses testing for differences in the bacterial communities between incubation time (Days), application rates of biochar and their interaction (Days $\mathrm{x}$ biochar rate) in sandy and clayey soils.

\begin{tabular}{ccccc}
\hline Source & SS & df & MS & F \\
Days & 0.656 & 3 & Sandy soil & \\
Biochar rate & 0.331 & 4 & 0.219 & $2.241^{*}$ \\
Days x Biochar rate & 0.106 & 12 & 0.083 & $0.847^{*}$ \\
& & & 0.009 & \\
Days & 0.958 & 2 & $0.091^{*}$ \\
Biochar rate & 0.694 & 4 & 0.174 & $5.892^{*}$ \\
Days x Biochar rate & 1.488 & 8 & 0.186 & $2.136^{*}$ \\
\hline
\end{tabular}

${ }^{*} p$-value $<0.001$. 


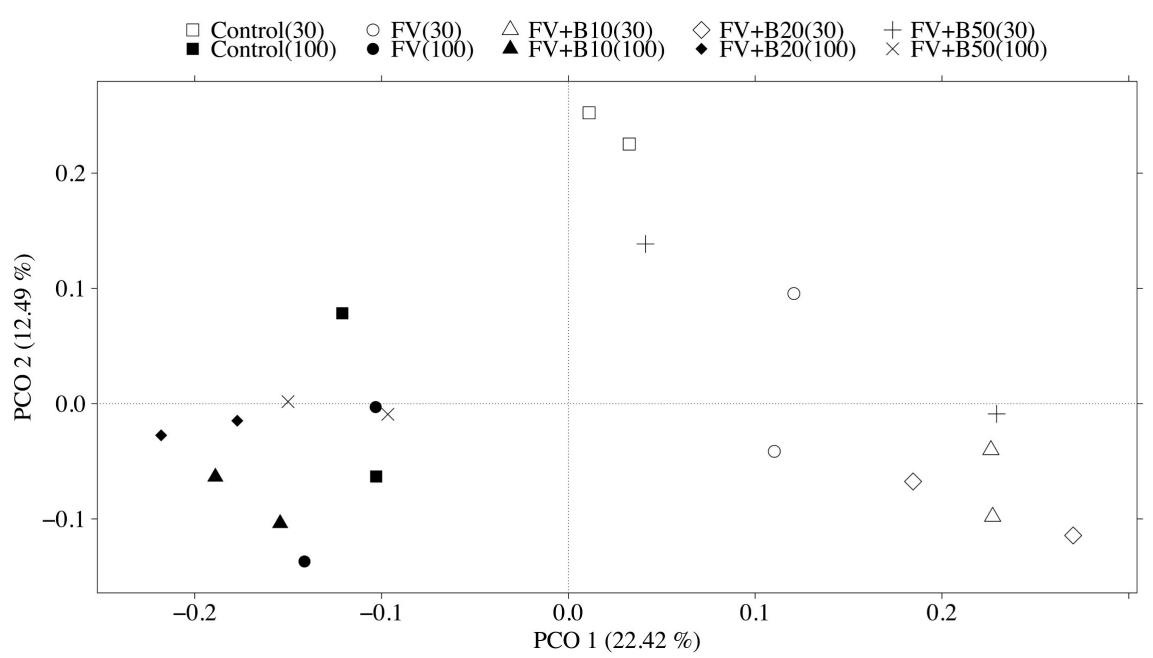

Figure 3. Principal coordinates analysis ( $\mathrm{PCoA})$ of the bacterial community distribution in sandy soil at 30 and 100 days of incubation. The treatments are: soil with filter cake and vinasse (FV); plus biochar at $10(\mathrm{FV}+\mathrm{B} 10), 20(\mathrm{FV}+\mathrm{B} 20)$ and $50(\mathrm{FV}+\mathrm{B} 50)$ $\mathrm{Mg} \cdot \mathrm{ha}^{-1}$.

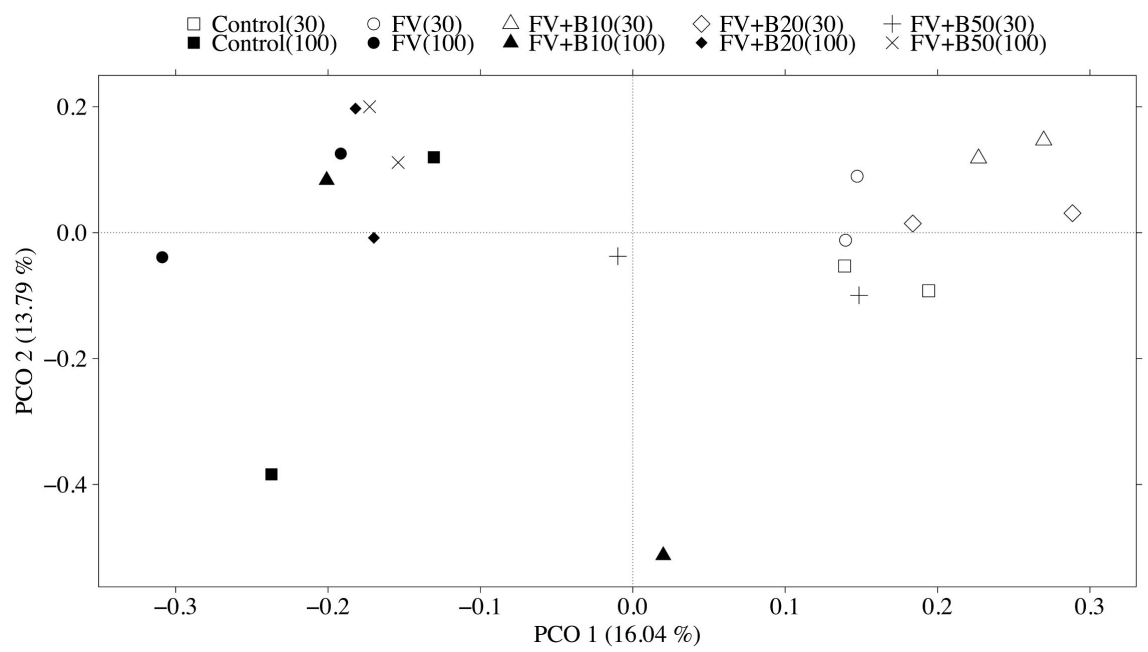

Figure 4. Principal coordinates analysis (PCoA) of the bacterial community distribution in clayey soil at 30 and 100 days of incubation. The treatments are: soil with filter cake and vinasse (FV); plus biochar at $10(\mathrm{FV}+\mathrm{B} 10), 20(\mathrm{FV}+\mathrm{B} 20)$ and $50(\mathrm{FV}+\mathrm{B} 50)$ $\mathrm{Mg} \cdot \mathrm{ha}^{-1}$.

terial community according to the amount [50], type [51] and persistence of the biochar applied to soil [40] [52].

According to [52], biochar have prompted the "charosphere", a region that surrounds its surface and it is permeated by many physical and chemical reactions, thus affecting soil $\mathrm{pH}$, release of soluble $\mathrm{C}$ and nutrients availability, which may differentially influence the soil bacterial structure and composition. Clustering the results of bacterial communities, mineral $\mathrm{N}$ and $\mathrm{N}_{2} \mathrm{O}$ emissions, it can be seen that the similar bacterial structure at 30 and 100 days of incubation in clayey soil ( $\mathrm{R}=0.24, p=0.0001)$ was concomitant with decreasing $\mathrm{NH}_{4}^{+}-\mathrm{N}$ and 
$\mathrm{NO}_{3}^{-}-\mathrm{N}$ concentrations (Table 3 ) and $\mathrm{N}_{2} \mathrm{O}$ emissions (Figure 2).

These results suggest that the interactions between biochar and the microbial community may drive the mitigation of GHG emissions, mainly $\mathrm{N}_{2} \mathrm{O}$. Most important, it seems that $\mathrm{N}_{2} \mathrm{O}$ emission mitigation in clayey soil is more directly related to biotic mechanisms (i.e. direct changes in microbial community composition through biochar addition to soil); while in sandy soil the abiotic mechanisms caused by biochar (e.g. acid neutralizing capacity, cation exchange properties) play a more important role in reducing $\mathrm{N}_{2} \mathrm{O}$ emissions, which in turn indirectly "activate" soil microbial communities to further reduce $\mathrm{N}_{2} \mathrm{O}$.

[53] showed the influence of biochar on temporal changes in bacterial community-either promoting an increase in abundance or reducing the magnitude of loss of species, a negative effect on bacterial abundance, and changes in the $\mathrm{N}$ cycling. The same authors showed that transcription factor peaks were closely related to bacterial groups such as Mycobacterium, which could play a crucial role in $\mathrm{NO}_{3}^{-}$reduction, and Bradyrhizobium, reducing $\mathrm{N}_{2} \mathrm{O}$ to $\mathrm{N}_{2}$. Therefore, this could be a mechanism to explain the mitigation of $\mathrm{N}_{2} \mathrm{O}$ emissions observed when biochar is applied to soil [54].

\section{Conclusion}

Biochar combined with filter cake and vinasse presented synergistic effects on soil $\mathrm{pH}$, availability of $\mathrm{P}$ and exchangeable bases contents. However, the effects of this combination on soil amelioration were closely related to the soil buffering capacity, suggesting soil-specific biochar interactions and the use of biochar not only as a soil conditioner, but also as a fertilizer itself in nutrient-poor tropical soils. Soil-biochar interactions caused temporal changes in bacterial communities both directly and indirectly, affecting niche-microbe interactions related to $\mathrm{N}_{2} \mathrm{O}$ emission mitigation. Thus, there was a significant supression of $\mathrm{N}_{2} \mathrm{O}$ emissions in contrasting soils treated with vinasse and filter cake as a function of biochar application rate.

\section{Acknowledgements}

The authors would like to thank the National Council for Scientific and Technological Development (CNPq), MCTI/CNPq/CT-AGRO Climate Change (Grant number CNPq/404150/2013-6), and the Sao Paulo State Research Foundation (FAPESP, Grant number 2012/19332-0) for financial support of this work.

\section{References}

[1] CONAB. Acompanhamento da safra brasileira: Cana-de-açúcar, quarto levantamento, abril/2013. Companhia Nacional de Abastecimento, Brasília, 2013.

http://www.conab.gov.br/

[2] Franco, H.C.J., Pimenta, M.T.B., Carvalho, J.L.N., Magalhães, PSG., Rossell, C.E.V., Braunbeck, O.A., Vitti, A.C., Kölln, O.T. and Neto, J.R. (2013) Assessment of Su- 
garcane Trash for Agronomic and Energy Purposes in Brazil. Scientia Agricola, 70, 305-312. https://doi.org/10.1590/S0103-90162013000500004

[3] Prado, R.M., Caione, G. and Campos, C.N.S. (2013) Filter Cake and Vinasse as Fertilizers Contributing to Conservation Agriculture. Applied and Environmental Soil Science, 98, 1-8. https://doi.org/10.1155/2013/581984

[4] Macedo, I.C., Seabra, J.E.A. and Silva, J.E.R. (2008) Greenhouse Gases Emissions in the Production and Use of Ethanol from Sugarcane in Brazil: The 2005/2006 Averages and a Prediction for 2020. Biomass and Bioenergy, 32, 582-595.

https://doi.org/10.1016/j.biombioe.2007.12.006

[5] Carmo, J.B., Filoso, S.Zotelli, L.C., Neto,E.R.S.,Pitombo, L.M., Duarte-Neto,P.J., Vargas, V.P., Andrade, C.A.,Gava, G.J.C., Rossetto, R., Cantarella, H., Neto, A.E. and Martinelli, L.A. (2013) Infield Greenhouse Gas Emissions from Sugarcane Soils in Brazil: Effects from Synthetic and Organic Fertilizer Application and Crop Trash Accumulation. Global Change Biology Bioenergy, 5, 267-280.

https://doi.org/10.1111/j.1757-1707.2012.01199.x

[6] Oliveira, B.G., Carvalho, J.L.N., Cerri, C.E.P., Cerri, C.C. and Feigl, B.J. (2013) Soil Greenhouse Gas Fluxes from Vinasse Application in Brazilian Sugarcane Areas. Geoderma, 200-201, 77-84. https://doi.org/10.1016/j.geoderma.2013.02.005

[7] Paredes, D.S., Lessa, A.C.R.,SantAnna, S.A.C., Boddey, R.M., Urquiaga, S. and Alves, B.J.R. (2013) Nitrous Oxide Emission and Ammonia Volatilization Induced by Vinasse and $\mathrm{N}$ Fertilizer Application in a Sugarcane Crop at Rio de Janeiro, Brazil. Nutrient Cycling in Agroecosystems, 98, 41-55. https://doi.org/10.1007/s10705-013-9594-5

[8] Glaser, B., Lehmann, J. and Zech, W. (2002) Ameliorating Physical and Chemical Properties of Highly Weathered Soils in the Tropics with Charcoal a Review. Biology and Fertility of Soils, 35, 219-230. https://doi.org/10.1007/s00374-002-0466-4

[9] Lehmann, J., Rillig, M.C., Thies, J., Masiello, C.A., Hockaday, W.C. and Crowley, D. (2011) Biochar Effects on Soil Biota: A Review. Soil Biology and Biochemistry, 43, 1812-1836. https://doi.org/10.1016/j.soilbio.2011.04.022

[10] Harvey, O.R., Kuo, L.J., Zimmerman, A.R., Louchouarn, P., Amonette, J.E. and Herbert, B.E. (2012) An Index-Based Approach to Assessing Recalcitrance and Soil Carbon Sequestration Potential of Engineered Black Carbons (Biochars). Environmental Science and Technology, 46, 1415-1142. https://doi.org/10.1021/es2040398

[11] Nelissen, V., Rutting, T., Huygens, D., Staelens, J., Ruysschaert, G. and Boeckx, P. (2012) Maize Biochars Accelerate Short-Term Soil Nitrogen Dynamics in a Loamy Sand Soil. Soil Biology and Biochemistry, 55, 20-27. https://doi.org/10.1016/j.soilbio.2012.05.019

[12] Cayuela, M.L., Sánchez-Monedero, M.A., Roig, A., Hanley, K., Enders, A. and Lehmann, J. (2013) Biochar and Denitrification in Soils: When, How much and Why Does Biochar Reduce $\mathrm{N}_{2} \mathrm{O}$ Emissions? Nature Scientific Reports, 3, 1-7. https://doi.org/10.1038/srep01732

[13] Clough, T., Condron, L., Kammann, C. and Müller, C. (2013) A Review of Biochar and Soil Nitrogen Dynamics. Agronomy Journal, 3, 275-293. https://doi.org/10.3390/agronomy3020275

[14] Mukherjee, A. and Lal, R. (2014) The Biochar Dilemma. Australian Journal of Soil Research, 52, 217-230. https://doi.org/10.1071/SR13359

[15] Ippolito, J.A., Spokas, K.A., Novak, J.M., Lentz, R.D. and Cantrell, K.B. (2015) Biochar Elemental Composition and Factors Influencing Nutrient Retention. In: Leh- 
mann, J. and Joseph, S., Eds., Biochar for Environmental Management, Earthscan, London, 137-162.

[16] Wang, J., Xiong, Z. and Kuzyakov, Y. (2016) Biochar Stability in Soil: Meta-Analysis of Decomposition and Priming Effects. Global Change Biology Bioenergy, 8, 512 523. https://doi.org/10.1111/gcbb.12266

[17] Fischer, D. and Glaser, B. (2012) Synergisms between Compost and Biochar for Sustainable Soil Amelioration. In: Kumar, S., Ed., Management of Organic Waste, In Tech, Rijeka and Shanghai, 167-198. https://doi.org/10.5772/31200

[18] Dias, B.O., Silva, C.A., Higashikawa, F.S., Roig, A. and Sánchez-Monedero, M.A. (2010) Use of Biochar as Bulking Agent for the Composting of Poultry Manure: Effect on Organic Matter Degradation and Humification. Bioresource Technology, 101, 1239-1246. https://doi.org/10.1016/j.biortech.2009.09.024

[19] Eykelbosh, A.J., Johnson, M.S., de Queiroz, E.S., Dalmagro, H.J. and Couto, E.G. (2014) Biochar from Sugarcane Filtercake Reduces Soil $\mathrm{Co}_{2}$ Emissions Relative to Raw Residue and Improves Water Retention and Nutrient Availability in a Highly-Weathered Tropical Soil. PLOS ONE, 9, Article ID: e98523. https://doi.org/10.1371/journal.pone.0098523

[20] Laird, D.A., Brown, R.C., Amonette, J.E. and Lehnann, J. (2009) Review of the Pyrolysis Platform for Coproducing Bio-Oil and Biochar. Biofuels Bioproducts and Biorefiniring, 3, 547-562. https://doi.org/10.1002/bbb.169

[21] Benke, M.B., Mermut, A.R. and Shariatmadari, H. (1999) Retention of Dissolved Organic Carbon from Vinasse by a Tropical Soil, Kaolinite, and Fe-Oxides. Geoderma, 91, 47-63. https://doi.org/10.1016/S0016-7061(98)00143-8

[22] Ribeiro, B.T., de Lima, J.M., Curi, N., de Oliveira, G.C. and Lima, P.L.T. (2011) Surface Charge of Clay Fraction as Affected by Vinasse and Phosphorus. Química Nova, 34, 5-10. https://doi.org/10.1590/S0100-40422011000100002

[23] Santos, D.H., Silva, M.A., Tiritan, C.S. and Crusciol, C.A.C. (2014) The Effect of Filter Cake Enriched with Soluble Phosphorus Used as a Fertilizer on the Sugarcane Ratoons. Acta Scientiarum Agronomy, 36, 365-372. https://doi.org/10.4025/actasciagron.v36i3.17791

[24] Cantarella, H. and Rossetto, R. (2008) Fertilizers for Sugarcane. In: Cortez, L.A.B., Ed., Sugarcane Bioethanol-R\&D for Productivity and Sustainability, Blucher, Sao Paulo, 405-422.

[25] Ruzicka, J. and Hansen, E.H. (1981) Flow Injection Analysis. Wiley Interscience, New York.

[26] Van Raij, B. and Quaggio, J.A. (1983) Métodos de Análise de Solo Para Fins de Fertilidade. Instituto Agronômico, Campinas.

[27] Embrapa (1997) Manual de Métodos de análise de Solo. Empresa Brasileira de Pesquisa Agropecuária, Rio de Janeiro.

[28] Whittaker, E.T. and Robinson, G. (1967) The Trapezoidal and Parabolic Rules. In: Whittaker, E.T. and Robinson, G., Eds., The Calculus of Observations: A Treatise on Numerical Mathematics, Cope Press, Dover, New York, 156-158.

[29] Muyzer, G., de Waal, E.C. and Uitterlinden, A.G. (1993) Profiling of Complex Microbial Populations by Denaturing Gradient Gel Electrophoresis Analysis of Polymerase Chain Reaction-Amplified Genes Coding for 16S rRNA. Applied and Environmental Microbiology, 59, 695-700.

[30] Heuer, H., Krsek, M., Baker, P., Smalla, K. and Wellington, E.M.H. (1997) Analysis 
of Actinomycete Communities by Specific Amplification of Genes Encoding 16S rRNA and Gel-Electrophoretic Separation in Denaturing Gradients. Applied Environmental Microbiology, 63, 3233-3241.

[31] McCaig, A.E., Glover, L.A. and Prosser, J.I. (2001) Numerical Analysis of Grassland Bacterial Community Structure under Different Land Management Regimes by Using 16S Ribosomal DNA Sequence Data and Denaturing Gradient Gel Electrophoresis Banding Patterns. Applied Environmental Microbiology, 67, 4554-4559. https://doi.org/10.1128/AEM.67.10.4554-4559.2001

[32] R Core Team (2014) R: A Language and Environment for Statistical Computing. R Foundation for Statistical Computing, Vienna. http://www.R-project.org/.

[33] Bray, J.R. and Curtis, J.T. (1957) An Ordination of the Upland Forest Communities of Southern Wisconsin. Ecological Monographies, 27, 325-349. https://doi.org/10.2307/1942268

[34] Hammer, O., Harper, D.A.T. and Rian, P.D. (2001) Past: Palaeontological Statistics Software Package for Education and Data Analysis. Version. 1.37.

http://palaeo-electronica.org/2001_1/past/issue1_01.htm

[35] Ribeiro, B.T., Lima, J.M., Curi, N. and Oliveira, G.C. (2012) Electrochemical Attributes of Soils Influenced by Sugarcane Vinasse. Bioscience Journal, 28, 25-32.

[36] Mbagwu, J.S.C. and Piccolo, A. (1997) Effects of Humic Substances from Oxidized Coal on Soil Chemical Properties and Maize Yield. In: Drozd, J., Gonet, S.S., Senesi, N. and Weber, J., Eds., The Role of Humic Substances in the Ecosystems and in Environmental Protection, Poland Polish Society of Humic Substances, Wroclaw, 921925.

[37] Yoshizawa, S., Tanaka, S., Ohata, M., Mineki, S., Goto, S., Fujioka, K. and Kokubun, T. (2005) Composting of Food Garbage and Livestock Waste Containing Biomass Charcoal. Proceedings of the International Conference and Natural Resources and Environmental Management, Kuching. http://www.biochar-international.org/

[38] Glaser, B., Haumaier, L., Guggenberger, G. and Zech, W. (2001) The Terra Preta Phenomenon: A Model for Sustainable Agriculture in the Humid Tropics. Naturwissenschaften, 88, 37-41. https://doi.org/10.1007/s001140000193

[39] Kameyama, K., Miyamoto, T., Shiono, T. and Shinogi, Y. (2012) Influence of Sugarcane Bagasse-Derived Biochar Application on Nitrate Leaching in Calcaric Dark Red Soil. Journal of Environmental Quality, 41, 1131-1137. https://doi.org/10.2134/jeq2010.0453

[40] Prommer, J., Wanek, W., Hofhansl, F., Trojan, D., Offre, P. and Urich, T. (2014) Biochar Decelerates Soil Organic Nitrogen Cycling but Stimulates Soil Nitrification in a Temperate Arable Field Trial. PLOS ONE, 9, 86-88. https://doi.org/10.1371/journal.pone.0086388

[41] Späth, A. and König, B. (2010) Molecular Recognition of Organic Ammonium Ions in Solution Using Synthetic Receptors. Beilstein Journal of Organic Chemistry, 6, 1-111. https://doi.org/10.3762/bjoc.6.32

[42] Jones, D.L., Rousk, J., Edwards-Jones, G., Deluca, T.H. and Murphy, D.V. (2012) Biochar-Mediated Changes in Soil Quality and Plant Growth in a Three Year Field Trial. Soil Biology and Biochemistry, 45, 113-124. https://doi.org/10.1016/j.soilbio.2011.10.012

[43] Nelissen, V., Saha, B.K., Ruysschaert, G. and Boeckx, P. (2014) Effect of Different Biochar and Fertilizer Types on $\mathrm{N}_{2} \mathrm{O}$ and NO Emissions. Soil Biology and Bioche- 
mistry, 70, 244-255. https://doi.org/10.1016/j.soilbio.2013.12.026

[44] Farrell, M., Kuhn, T.K., Macdonald, L.M., Maddern, T.M., Murphy, D.V., Hall, P.A., Singh, B.P., Baumann, K., Krull, E.S. and Baldock, J.A. (2013) Microbial Utilisation of Biochar-Derived Carbon. Science of the Total Environment, 465, 288-297. https://doi.org/10.1016/j.scitotenv.2013.03.090

[45] Zimmerman, A.R., Gao, B. and Ahn, M.-Y. (2011) Positive and Negative Carbon Mineralization Priming Effects among a Variety of Biochar-Amended Soils. Soil Biology and Biochemistry, 43, 1169-1179. https://doi.org/10.1016/j.soilbio.2011.02.005

[46] Singh, B.P. and Cowie, A.L. (2014) Long-Term Influence of Biochar on Native Organic Carbon Mineralisation in a Low-Carbon Clayey Soil. Scientific Reports, 4, 1-9.

[47] Schulz, H., Dunst, G. and Glaser, B. (2013) Positive Effects of Composted Biochar on Plant Growth and Soil Fertility. Agronomy for Sustainable Development, 33, 817-827. https://doi.org/10.1007/s13593-013-0150-0

[48] Maestrini, B., Nannipieri, P. and Abiven, S. (2015) A Meta-Analysis on Pyrogenic Organic Matter Induced Priming Effect. Global Change Biology Bioenergy, 7, 577590. https://doi.org/10.1111/gcbb.12194

[49] Demisie, W., Liu, Z. and Zhang, M. (2014) Effect of Biochar on Carbon Fractions and Enzyme Activity of Red Soil.Catena, 121, 214-221. https://doi.org/10.1016/j.catena.2014.05.020

[50] Kolton, M., Harel, Y.M., Pasternak, Z., Graber, E.R., Elad, Y. and Cytryn, E. (2011) Impact of Biochar Application to Soil on the Root-Associated Bacterial Community Structure of Fully Developed Greenhouse Pepper Plants. Applied and Environmental Microbiology, 77, 4924-4930. https://doi.org/10.1128/AEM.00148-11

[51] Khodadad, C.L.M., Zimmerman, A.R., Green, S.J., Uthandi, S. and Foster, J.S. (2011) Taxa-Specific Changes in Soil Microbial Community Composition Induced by Pyrogenic Carbon Amendments. Soil Biology and Biochemistry, 43, 385-392. https://doi.org/10.1016/j.soilbio.2010.11.005

[52] Quilliam, R.S., Marsden, K.A., Gertler, C., Rousk, J., DeLuca, T.H. and Jones, D.L. (2012) Nutrient Dynamics, Microbial Growth and Weed Emergence in Biochar Amended Soil Are Influenced by Time Since Application and Reapplication Rate. Agriculture, Ecosystems and Environment, 158, 192-199. https://doi.org/10.1016/j.agee.2012.06.011

[53] Anderson, C.R., Condron, L.M., Clough, T.J., Fiers, M., Stewart, A., Hill, R.A. and Sherlock, R.R. (2011) Biochar Induced Soil Microbial Community Change: Implications for Biogeochemical Cycling of Carbon, Nitrogen and Phosphorus. Pedobiologia, 54, 309-320. https://doi.org/10.1016/j.pedobi.2011.07.005

[54] Rondon, M.A., Lehmann, J., Ramirez, J. and Hurtado, M. (2007) Fisiological Nitrogen Fixation by Common Beans (Phaseolus vulgaris L) Increases with Biochar Additions. Biology and Fertility of Soils, 43, 699-708.

https://doi.org/10.1007/s00374-006-0152-Z 
Submit or recommend next manuscript to SCIRP and we will provide best service for you:

Accepting pre-submission inquiries through Email, Facebook, LinkedIn, Twitter, etc. A wide selection of journals (inclusive of 9 subjects, more than 200 journals)

Providing 24-hour high-quality service

User-friendly online submission system

Fair and swift peer-review system

Efficient typesetting and proofreading procedure

Display of the result of downloads and visits, as well as the number of cited articles Maximum dissemination of your research work

Submit your manuscript at: http://papersubmission.scirp.org/

Or contact as@scirp.org 